\title{
FRUGIVOROUS BIRDS AND FRUIT PLANTS IN A DECIDUOUS FOREST IN BANGLADESH: A CASE STUDY IN THE MADHUPUR NATIONAL PARK
}

\author{
Shawkat Imam Khan* and M. Farid Ahsan ${ }^{1}$ \\ Department of Natural History, Bangladesh National Museum \\ Shahbag, Dhaka 1000, Bangladesh
}

\begin{abstract}
A total of 29 species of frugivorous birds were recorded from the Madhupur National Park during July 2007 to December 2008. Among the frugivorous birds, 16 (55.2\%) were absolutely seed gulpers, 2 (6.9\%) seed gulpers as well as seed discarders and $5(17.2 \%)$ were fully seed predators. The frugivorous birds were observed more active during early morning (23 species, 79.3\%) and late afternoon (20 species, 69\%), of which $16(55.2 \%)$ were common in both time frames. Frugivorous birds mainly preferred fruit followed by nectars, seeds and buds. Ficus benghalensis was the top most preferred food plant to the birds. Berries were highly preferred $(29.7 \%)$ by the birds. The preferred fruit diameter ranged from 16.5 to $19.6 \mathrm{~mm}(18.1 \pm 0.8)$. Black colour and mild sweet fruit was highly preferred by the birds.
\end{abstract}

Key words: Fruit eating birds, fruit plants, deciduous forest, Bangladesh.

\section{INTRODUCTION}

Birds are considered a good indicator of the biodiversity. Because they occupy a wide range of habitats from open field to forest, desert to highmountain and even to ice zone, can reflect change in other animals and plants, can be sensitive to environmental change and they tend to be near or at the top of the food chain (Estrada et al. 1993). Birds are, therefore, good indicators of healthy forests and natural environment.

Frugivorous are those birds that feed primarily on fruits and seeds for their survival (Anon. 2008). In tropical rainforest, fruit-eating birds are particularly important seed dispersers, because up to $75 \%$ of tree species produce fruits eaten by birds (Herrera et al. 1994). Frugivorous birds have the basic mechanism of seed dispersal that allows birds to carry seeds from the parent plants to the new environment for their successful germination (Levey et al. 2002). Most of the plants are dispersed and spread populations through their seeds and spores (Terborgh 1986).

Frugivorous birds usually depend on fruits provided by the plants of both natural and planted. Besides they also devour nectars, flowers, buds, seeds and insects during fruit lean period. However, specific dietary information on

* Corresponding author: shawkat194@gmail.com. 1Department of Zoology, University of Chittagong, Chittagong 4331, Bangladesh

(C) 2015 Zoological Society of Bangladesh DOI: $10.3329 / \mathrm{bjz} \cdot \mathbf{v} 43 i 2.27390$ 
frugivorous birds is limited. In such cases, fruit-seed crushing behaviour and relative dietary dominance by fruits may be used to describe the role of frugivores in seed dispersal. Successful seed dispersal is the out come of a mutual interaction between birds and plants (Anon 2008). Fruit morphology, such as fruit and seed size, and seed geometry affect food choice of birds (Herrera 1984, Howe 1984, Murray et al. 1993).

No published work on food, food plant preference and food composition of frugivorous birds of deciduous forest in Bangladesh is on record. This work has provided information on food, feeding, foraging and food preference of frugivorous birds in Bangladesh. So, an attempt was taken to do that to make a base line of future research on the frugivorous bird species in Bangladesh. The objectives were to: (a) record frugivorous bird species in a deciduous forest, (b) find out different foraging activities, and (c) enlist plant species which were used by birds for food items.

\section{MATERIAL AND METHODS}

The study was carried out at the Madhupur National Park (MNP), Tangail, Bangladesh during July 2007 to December 2008. It is situated in the northern part of Bhawal-Madhupur Shal (Shorea robusta) forest tract $\left(24^{\circ}\right.$ to $25^{\circ} 15^{\prime} \mathrm{N}$ and $90^{\circ}$ to $91^{\circ} \mathrm{E}$, about $20 \mathrm{~m}$ above the mean sea level), $151 \mathrm{~km}$ north of Dhaka, the capital of Bangladesh and $50 \mathrm{~km}$ south of the Garo Hills of the Meghalaya State of India. Madhupur Shal forest includes an area of about 24,150 ha, but the Madhupur National Park (wildlife and recreation area) encompasses an area of 8,430 ha.

The forest is partly dense and partly thin including some scrub jungles and human settlements. There are numerous depressions with gentle slope intercepting the ridges. Flat ridges run north to south forming the irregular masses of high lands with gentle slopes. In rainy season, the low-lying depressions accumulate water and become marshy. These marshy places dry up in summer and winter seasons but they expand into broad shallow areas. These shallow swampy areas are covered with grasses and reeds, and harbour some aquatic birds.

The climate is moderate and warm weather spread over March to October; maximum temperature was $37.6^{\circ} \mathrm{C}$ in April 2008. The cold weather lasts from November to February with a minimum temperature of $7.8^{\circ} \mathrm{C}$ recorded in February 2008. The monthly average rainfall was about $154.7 \mathrm{~mm}$ and the yearly $2,091 \mathrm{~mm}$. The average maximum humidity varied from 97 to $100 \%$ and minimum 20 to $58 \%$. The MNP is dominated by Shal trees associated with other tree species.

The area was surveyed fortnightly from 0500 to $1800 \mathrm{~h}$. The working schedule was 2 - 3 days in each visit. The time schedule was depending on the seasonal variations. The survey was carried out through simple, Transect Sampling (Buckland et al. 2001) technique. Each transect was repeated twice in 
a day. The observation-range varied from 20 to $25 \mathrm{~m}$ depending on the visibility of the study area.

All bird species were identified following Ali and Ripley (1996) and Grimmett et al. (1998). Observations were made with naked eyes and with the help of a pair of binoculars (Bushnell 20 X $280 \mathrm{~mm}$ with multicoated lens) depending on the distance. Plant parts other than fruits eaten by the frugivorous birds were also recorded.

The local status of each species of bird was assessed based on the percentage of occurrence during observations (Khan 1982): Very Common (VC), Common (C), Fairly Common (FC), and Rare (R).

Food (fruit and seed) handling techniques (swallow the whole fruit, crushing before swallowing, pecking the fruit and cracking the seed) of different fruit eating birds were recorded in long hand notes. Data of handling techniques based on fruit size, shape, colour and taste were recorded. Feeding patterns, feeding association, feeding methods and canopy utilization by the frugivorous birds were also recorded through direct field observations.

The diets (fruit, seed, nectar, petal and bud) were assessed by direct feeding observations during transect walks. Samples of fruits and seeds were collected throughout the study period, regardless of whether they were eaten or not. The size of fresh fruits and seeds were measured with digital calipers $\left(0^{\prime \prime}-6^{\prime \prime} / 0-150\right.$ $\mathrm{mm}$ ) and weighed with a digital pocket balance (Kern Germany, Max $=60 \mathrm{~g}, \mathrm{~d}=$ $0.01 \mathrm{~g})$ at the field station. The measurements were taken from 30, sometimes from 10 fruit samples to establish an average.

\section{RESULTS AND DISCUSSION}

Frugivorous bird species: Twenty-nine species of frugivorous birds were recorded from MNP (Table 1), which comprised 5 orders and 11 families. The highest number (7 i.e., 24\%) of frugivorous birds species belong to the Family Corvidae. Anon. (2008) reported that the highest number of frugivorous birds (6) came from the Family Columbidae from five protected areas in Bangladesh. The families Centropodidae, Irenidae, Zosteropidae and Sylviidae comprised the lowest number (1 i.e., 3\%) of frugivorous species.

Among the recorded frugivorous birds, 17 were locally very common, 8 were common, 3 were fairly common and only one was rare.

Category of frugivorous birds: The frugivorous birds were categorized as seed gulpers- swallow whole fruit or fruit part containing seed (Gosper et al. 2005), seed discarders- take part or whole fruit without ingesting the seed (Jordano 1995) and seed predators- lethally damage the seed during foraging, either during mandibulation or during gut passage (Gosper et al. 2005). Among the frugivorous birds in MNP, 16 (55.2\%) were absolutely seed gulpers, 2 (6.9\%) seed gulpers as well as seed discarders, $5(17.2 \%)$ fully seed predators and the rest $6(20.7 \%)$ were nectar drinker as well as insect eater. 
Table 1. Recorded frugivorous bird species at the Madhupur National Park.

\begin{tabular}{|c|c|c|c|}
\hline $\begin{array}{l}\text { Order } \\
\text { Family }\end{array}$ & Common Name & Scientific Name & $\begin{array}{l}\text { Code } \\
\text { used }\end{array}$ \\
\hline \multicolumn{4}{|l|}{ Piciformes } \\
\hline \multirow[t]{3}{*}{ Megalaimidae } & 1. Lineated Barbet & Megalaima lineata (Vieillot 1816) & LB \\
\hline & 2. Coppersmith Barbet & $\begin{array}{l}\text { Megalaima haemacephala (Muller } \\
\text { 1776) }\end{array}$ & $\mathrm{CB}$ \\
\hline & 3. Blue-Throated Barbet & $\begin{array}{l}\text { Megalaima asiatica (Latham } \\
\text { 1790) }\end{array}$ & BTB \\
\hline \multicolumn{4}{|l|}{ Cuculiformes } \\
\hline Centropodidae & 4. Asian Koel & $\begin{array}{l}\text { Eudynamys scolopacea (Linnaeus } \\
\text { 1758) }\end{array}$ & $\mathrm{AK}$ \\
\hline \multicolumn{4}{|l|}{ Psittaciformes } \\
\hline \multirow[t]{2}{*}{ Psittacidae } & 5. Rose-ringed Parakeet & Psittacula krameri (Scopoli 1769) & $\mathrm{RRP}$ \\
\hline & 6. Red-breasted Parakeet & $\begin{array}{l}\text { Psittacula alexandri (Linnaeus } \\
1758 \text { ) }\end{array}$ & RBP \\
\hline \multicolumn{4}{|l|}{ Columbiformes } \\
\hline \multirow[t]{3}{*}{ Columbidae } & $\begin{array}{l}\text { 7. Yellow-footed Green } \\
\text { Pigeon }\end{array}$ & $\begin{array}{l}\text { Treron phoenicoptera (Latham } \\
\text { 1790) }\end{array}$ & YFGP \\
\hline & $\begin{array}{l}\text { 8. Thick-billed Green } \\
\text { Pigeon }\end{array}$ & Treron curvirostra (Gmelin 1789) & TBGP \\
\hline & $\begin{array}{l}\text { 9. Orange-breasted Green } \\
\text { Pigeon }\end{array}$ & Treron bicincta (Jerdon 1840) & OBGP \\
\hline \multicolumn{4}{|l|}{ Passeriformes } \\
\hline Irenidae & $\begin{array}{l}\text { 10. Golden-fronted } \\
\text { Leafbird }\end{array}$ & $\begin{array}{l}\text { Chloropsis aurifrons (Temminck } \\
\text { 1829) }\end{array}$ & GFLB \\
\hline \multirow[t]{7}{*}{ Corvidae } & 11. Large Cuckooshrike & Coracina macei (Lesson 1831) & LCS \\
\hline & 12. House Crow & Corvus splendens (Vieillot 1817) & $\mathrm{HC}$ \\
\hline & 13. Large-billed Crow & $\begin{array}{l}\text { Corvus macrorhynchos (Wagler } \\
\text { 1827) }\end{array}$ & LBC \\
\hline & 14. Black-hooded Oriole & $\begin{array}{l}\text { Oriolus xanthornus (Linnaeus } \\
1758 \text { ) }\end{array}$ & $\mathrm{BHO}$ \\
\hline & 15. Black-naped Oriole & Oriolus chinensis (Linnaeus 1758) & $\mathrm{BNO}$ \\
\hline & 16. Rufous Treepie & $\begin{array}{l}\text { Dendrocitta vagabunda (Latham } \\
\text { 1790) }\end{array}$ & $\mathrm{RT}$ \\
\hline & 17. Common Iora & Aegithina tiphia (Linnaeus 1758) & $\mathrm{CI}$ \\
\hline \multirow[t]{4}{*}{ Sturnidae } & 18. Common Myna & $\begin{array}{l}\text { Acridotheres tristis (Linnaeus } \\
\text { 1766) }\end{array}$ & $\mathrm{CM}$ \\
\hline & 19. Jungle Myna & Acridotheres fuscus (Wagler 1827) & $\mathrm{JM}$ \\
\hline & 20. Asian-pied Starling & Sturnus contra (Linnaeus 1758) & APS \\
\hline & $\begin{array}{l}\text { 21. Chestnut-tailed } \\
\text { Starling }\end{array}$ & $\begin{array}{l}\text { Sturnus malabaricus (Gmelin } \\
\text { 1789) }\end{array}$ & CTS \\
\hline Pycnonotidae & 22. Red-vented Bulbul & Pycnonotus cafer (Linnaeus 1766) & RVB \\
\hline
\end{tabular}




\begin{tabular}{|c|c|c|c|}
\hline $\begin{array}{l}\text { Order } \\
\text { Family }\end{array}$ & Common Name & Scientific Name & $\begin{array}{l}\text { Code } \\
\text { used }\end{array}$ \\
\hline & 23. Red-whiskered Bulbul & $\begin{array}{l}\text { Pycnonotus jocosus (Linnaeus } \\
1758 \text { ) }\end{array}$ & RWB \\
\hline Zosteropidae & 24. Oriental White-eye & $\begin{array}{l}\text { Zosterops palpebrosus (Temminck } \\
1824)\end{array}$ & OWE \\
\hline Sylviidae & 25. Jungle Babbler & Turtoides striatus (Dumont 1823) & $\mathrm{JB}$ \\
\hline \multirow[t]{4}{*}{ Nectariniidae } & 26. Purple Sunbird & Nectarinia asiatica (Latham 1790) & PS \\
\hline & $\begin{array}{l}\text { 27. Purple-rumped } \\
\text { Sunbird }\end{array}$ & $\begin{array}{l}\text { Nectarinia zeylonica (Linnaeus } \\
\text { 1766) }\end{array}$ & PRS \\
\hline & 28. Little Spiderhunter & $\begin{array}{l}\text { Arachnothera longirostra (Latham } \\
\text { 1790) }\end{array}$ & LS \\
\hline & $\begin{array}{l}\text { 29. Pale-billed } \\
\text { Flowerpecker }\end{array}$ & $\begin{array}{l}\text { Dicaeum erythrorynchos (Latham } \\
\text { 1790) }\end{array}$ & $\mathrm{PBF}$ \\
\hline
\end{tabular}

Foraging time: All the recorded frugivorous birds visited the food plants throughout the day for foraging. These birds were found more active during early morning (23 species, 79.3\%) and late afternoon (20 species, 69\%). This also supports the observations of Raju (2005) in the Eastern Ghats forests of India. This is because they eat more food in the morning after an overnight fasting and again consume more food at the late afternoon for taking an overnight fasting preparation. The peak activity of fruit-eating occurs in the early morning in tropics (Land 1963, Leck 1969, 1971, McDiarmid et al. 1977, Howe 1977, Leighton 1982) and fruit patches become depleted later in the day (Lambert 1987).

Foraging pattern: In MNP $15(51.7 \%)$ species of frugivorous birds were recorded as silent feeders and on the other hand, $14(48.3 \%)$ were found to be noisy feeders. Among the silent feeders, $6(40 \%)$ species were passerines and 9 (60\%) non-passerines; $14(93.3 \%)$ species were resident birds and the rest 1 $(6.7 \%)$ was migratory; all noisy feeder species $(100 \%)$ were passerines and resident.

Feeding association: Considering the feeding association, frugivorous birds were categorized into three groups: (1) group feeders, (2) solitary feeders and (3) group as well as solitary feeders. The group feeding species were the highest (15 i.e., $51.7 \%$ species) followed by solitary feeders (10 i.e., 34.5\%) and group and solitary feeders (4 i.e., 13.8\%) in MNP. Among the group feeders, 10 (66.7\%) species were passerines and $5(33.3 \%)$ non-passerines and all of these were resident species. In case of solitary feeders, $6(60 \%)$ species were passerines, 4 (40\%) non-passerines, and 9 (90\%) were resident and only 1 (10\%) was migratory species. All group as well as solitary feeders were passerines and resident species.

Canopy used: Vertically canopy was classified as: lower $(0-5 \mathrm{~m})$, middle $(5-$ $10 \mathrm{~m})$ and upper $(10 \mathrm{~m}>$ ) on the basis of the height from the ground level. Eight 
species of birds used all canopies for foraging (27.6\% species); 6 species used only upper canopy $(20.7 \%)$ and on the other hand, 15 species preferred mostly using middle and upper canopies (51.7\%).

Feeding methods: Frugivorous birds exercised three techniques (pick, reach up and reach down) to eat fruit. Fifteen species used all three techniques for feeding $(51.7 \%)$. Thirteen species $(44.8 \%)$ preferred to pick as well as reach up technique, but only Asian Koel always applied pick method during feeding.

Food preference: Fruit production period and duration of fruit availability might influence the fruit choice. Fruit size, fruit quantity, chance of accessibility of birds, plant structure and fruit taste also have impact on the fruit choice of birds. In the study area during food scarcity period, the frugivorous birds changed their choice from fruits to seeds, nectars and buds. They mainly preferred fruits followed by nectars, seeds and buds (Fig. 1). Blake and Loiselle (1992) found that the availability of fruits depending on season causes dietary shifts by frugivorous animals. Fatem et al. (2008) reported that birds consumed young leaves or shoots, ripe fruits, husk of fruits and inflorescence in Papua New Guinea. Beside fruits the frugivorous birds also eat shoots, buds and flower nectars during fruit scarcity (Anon 2008).

\section{Fruit $\square$ Seed $\mathbf{D}$ Nectar $\square$ Bud}

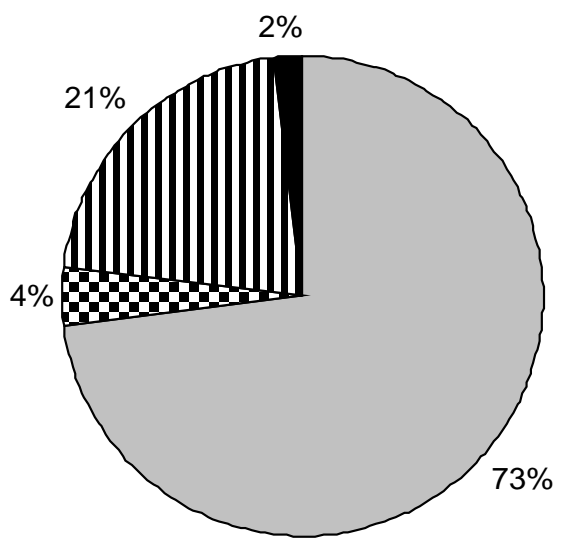

Fig. 1. Percentage of food plant species used in relation to food items.

Fruit handling techniques: All the species used beak for swallowing their foods except 4 species (2 parakeets and 2 crows). Parakeets and crows used beak and feet for eating fruits and seeds. Before swallowing fruit, the Parakeets picked up the fruit by beak, hold the fruit with one foot (either left or right) and ate the fruit pulp with beak and then swallowed. In case of seed, Parakeets picked up the fruit by beak and then cracked the fruit shell to extract/peel the 
seed and swallowed. Crows followed to some extent different techniques to eat fruit, they picked up the fruit from the tree branch with their beak and flew away to another branch of the same tree or any other support, then they kept the fruit from the beak on a support and held the fruit with foot (left or right) and then ate the fruit pulp through pecking in little pieces, raised the beak upward and swallowed.

Swallowing methods: During field observations different types of swallowing method (i.e., swallowing whole fruit, crushing fruit before swallowing, plucking before swallowing and seed cracking) were recorded.

Eighteen species $(62.1 \%)$ preferred to swallow the whole fruit. Seventeen species $(58.6 \%)$ were observed to pick up the fruit pulp before swallowing. Eight species $(27.6 \%)$ preferred to crush the fruit before swallowing, and only 5 species $(17.2 \%)$ were found to crack the seed shell before swallowing the inner part of the seed.

Among the frugivorous birds, Asian Koel, Yellow-footed Green Pigeon, Thickbilled Green Pigeon and Orange-breasted Green Pigeon always swallowed the whole fruit or crushed the fruit before swallowing. House Crow and Large-billed Crow never swallowed the whole fruit; these two species always picked up the fruit pulp through pecking before swallowing. The Lineated Barbet was the only bird, which mostly used crushed method to swallow the fruit, Red-vented Bulbul was the highest pulp picker and Parakeets were the highest seed cracker. Most species of fruit-eating birds either crush fruit during mandibulation, often dropping the seeds, or swallow intact fruits with little mandibulation (Moermond and Denslow 1985).

Time requirement to swallow the food: The time taken/required to manipulate food by frugivorous birds varied from species to species and even within a species depending on the size, texture and parts of the fruits. The Coppersmith Barbet, Green-billed Malkoha, Common Myna, Red-vented Bulbul, Jungle Bubbler and Pale-billed Flower-pecker took minimum time ( 3 seconds) and Rose-ringed Parakeet took maximum time (80 seconds) to manipulate and swallow food. Foster (1987) noted that usually birds require only a few seconds or less to manipulate the fruit from the tip of the bill to the back of the throat. In fact, birds took short time to manipulate and swallow small and soft textured fruits (e.g., Trema orientalis, Phyllanthus reticulates, Glycosmis pentaphyla, Solanum nigrum and Clerodendrum viscosum) and took long time to do so in case of seeds having hard shells (seed coats) (e.g., Albizia procera, Mellotus philippensis and Miliusa velutina).

Monthly variation: The highest number of species recorded in February and May 2008 (18 species, 62.1\%) and the lowest in September 2007 and October 2008 (2 species, 6.9\%).

Seasonal variation: The highest $22(75.9 \%)$ species was recorded both in winter (November - February) and in pre-monsoon (March-May). On the other 
hand, the lowest 21 species (72.4\%) was recorded in monsoon (June - October). But Takanose and Kamitani (2003) recorded the highest population of frugivorous birds in the fall (September - November) and the lowest in winter (December - February) in temperate forest of central Japan.

Used food plants by the frugivorous bird species: During this study period frugivorous bird species used 48 species of plants (under 19 families) for food. Among these $12(25 \%)$ species were food plants and $36(75 \%)$ species forest plants.

At MNP 34 species (70.8\%) of the 48 food plant species were big trees and the rest small trees (2, i.e., 4.2\%), shrubs (9, i.e., $18.7 \%$ ) and herbs (3, i.e., $6.3 \%$ ). There was a statistically highly significant difference between the numbers of frugivorous bird species using three plant habits (tree, herb and shrub) during feeding $\left(\chi^{2}=18.421, \mathrm{df}=2, \mathrm{p}<0.001\right)$.

The Family Moraceae comprised the highest number of plant species that provided foods to the frugivorous birds (12 species, i.e. 25\%) and the second highest Family was Myrtaceae (6 species, i.e., 13\%).

Local status of the used food plant species: Among the recorded food plant species used by the frugivorous bird species at MNP, only $1(2.1 \%)$ species was locally Very Common, 7 (14.6\%) were Common, 9 (18.7\%) Fairly Common and $31(64.6 \%)$ Rare.

Single and multiple fruit producers: During the study period 42 food plant species were recorded as one time fruit producer in a year, 3 species two times producer and 2 species produced fruits 3 or more times in a year.

Preferred food plant species: Ficus benghalensis was the top most preferred food plant. This plant species supported the diet of $13(44.8 \%)$ species of birds. Fogden (1970) found that figs are important dietary component for Barbets in Sarawak of East Malaysia. In Trinidad, 13 species of Tanagers and Honeycreepers feed on the fruits of three species of Ficus (Snow 1971). The fruits of Ficus species are of species interest (Snow 1981). The author also commented that figs are among the most important food of specialized frugivores in Africa, Southeast Asia and Australia.

Food plant preference on the basis of plant family: Food-plants belonging to the Family Moraceae were the most favourites to the frugivorous birds followed (12 species, i.e. 25\%) by Myrtaceae and Euphorbiaceae (Fig. 2). The Family Lauraceae, Burseraceae and Palmae get the outstanding importance by the frugivorous birds in Neotropical Region (Snow 1981). The author also stated that fruits of Myrtaceae are regularly taken by both specialized and unspecialized frugivores in all regions. Like the Myrtaceae, many genera of the Euphorbiaceae provide fruits that are eaten by frugivorous birds (Snow 1981). Leighton and Leighton (1983) identified the Meliaceae, Myristicaceae, Annonaceae and Moraceae are being important to the frugivorous birds. 


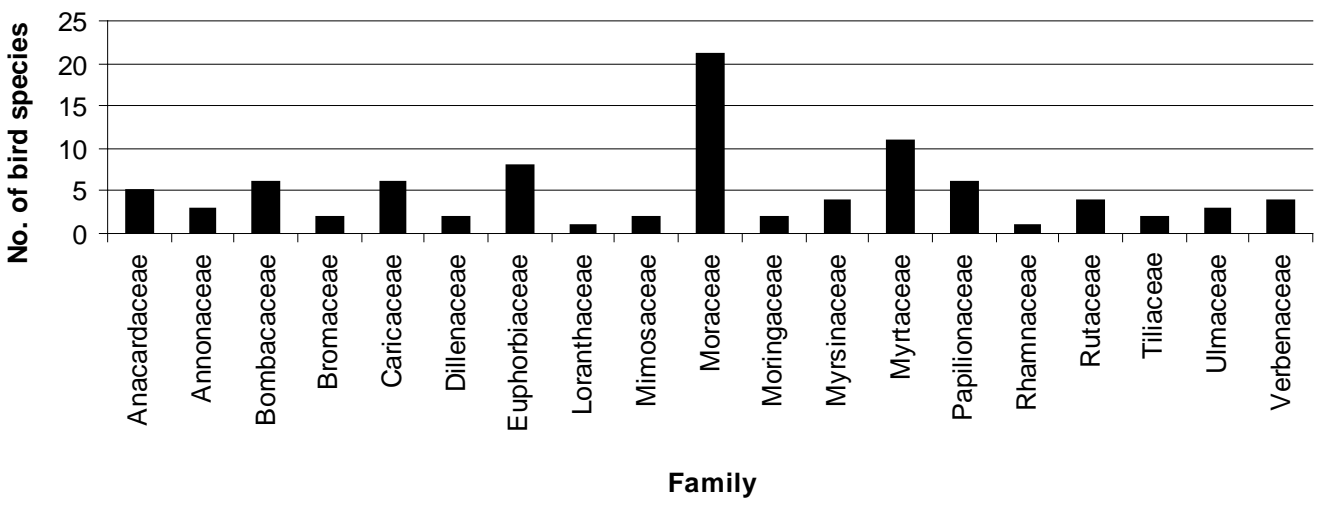

Fig. 2. Food preference on the basis of plant family.

Fruit preference on the basis of fruit type: Frugivorous birds ate 9 types of fruit (Drupe, Berry, Legume, Capsule, Nut, Carcerule, Syconus, Sorosis and Etaerio of Follicles). Among these berries were highly preferred (29.7\%). The second preference was both drupe and syconus (21.6\%). The difference between fruit types eaten and the number of frugivorous bird species was found to be statistically insignificant $\left(\chi^{2}=4.12\right.$, df $\left.=3, p>0.05\right)$.

Fruit preference on the basis of edible parts: Frugivorous birds prefer to eat different parts of the fruit. In MNP, 10 (34.5\%) of 29 birds had a preference to eat whole fruit. On the other hand, whole fruit or only mesocarp eating birds were $3.5 \%$, whole fruit or pericarp with mesocarp eaters were $31 \%$, and $3.5 \%$ birds preferred only whole fruit or 3 layers of a fruit (pericarp, epicarp and mesocarp). Only epicarp and mesocarp eating birds were $6.9 \%$ and mesocarp with seed-eaters were $3.5 \%$. Furthermore, $3.5 \%$ birds were recorded to eat young fruits.

Fruit preference on the basis of fruit diameter: The diameter of the edible fruit ranged from 2.1 to $400 \mathrm{~mm}(\mathrm{n}=35$ fruit species) and the preferred range varied from 16.5 to $19.6 \mathrm{~mm}(18.1 \pm 0.8)$ (Fig. 3). Small-fruited plant species attract more species of birds than large fruited ones (Terborgh and Diamond 1970). Fruit and seed size are important in fruit selection for frugivorous birds (Snow 1971, Mckey 1975, Howe and Estabrook 1977, Howe and van de Kerckhove 1980). Kantak (1979) mentioned that the intermediate sized-fruits attracting the greatest number of bird species. The size of bird-dispersed figs at Kuala Lompat ranged from the small ( $4 \mathrm{~mm}$ diameter fig, Ficus sinuate) to the relatively hugesized fig (45.5 X $34.8 \mathrm{~mm}$, F. subcordata) (Lambert 1987). Fruits of less than 20 $\mathrm{mm}$ diameter are to be primarily adapted for seed dispersal by volant birds (Willson et al. 1989). 


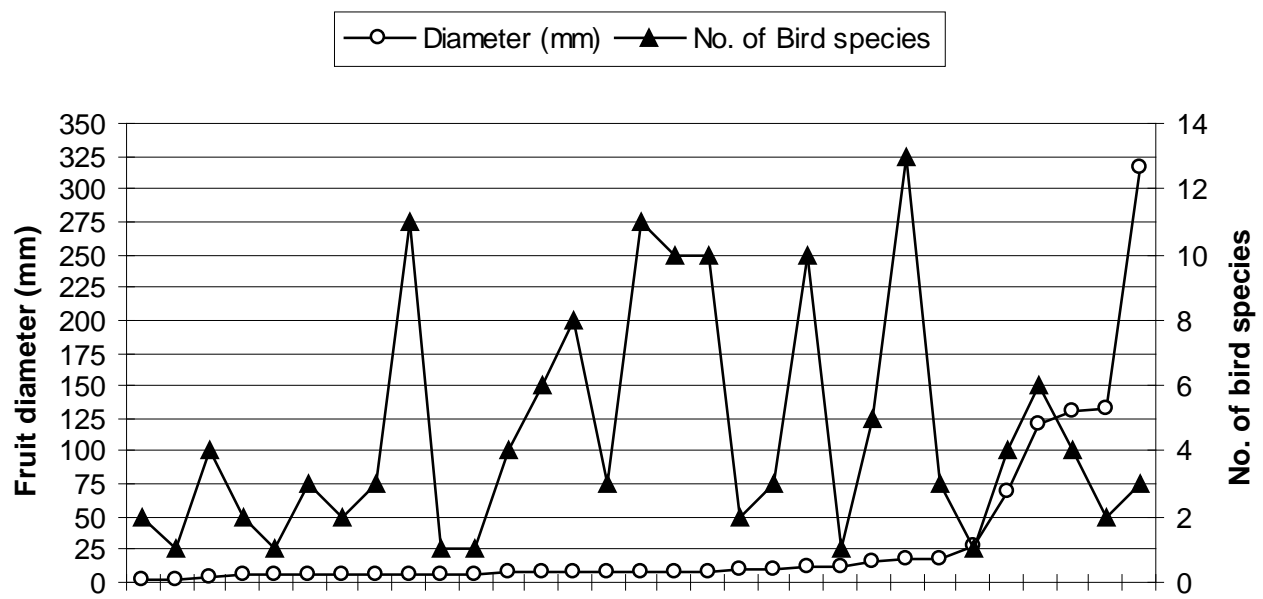

Fig. 3. Fruit preference based on fruit diameter.

Fruit choice on the basis of fruit colour: Altogether 13 colours (yellow, light yellow, black, green, red, light green, brown, yellowish brown, orange, violet, pink, light pink and rusty grey) of fruit were eaten by the frugivorous birds at MNP. Birds highly preferred black coloured-fruits $(20.8 \%$ of the total used plant species at MNP), this also supports the observations made by Wheelwright and Janson (1985) in Costa Rica, Peru and Florida. Dowselt-Lemaire (1988) mentioned that red/black were the most important colours of fruit eaten by birds. At Point Calimere Wildlife Sanctuary in South India red followed by black coloured fruits are preferred by birds (Balasubramanian 1996). The fruit choice was dominated in the samples are red, green and yellow respectively (Willson and Thomson 1982, Kamruzzaman and Asmat 2008).

Fruit preference on the basis of fruit taste: Seven categories of fruit taste (sweet, mild sweet, sour, mild sour, mild sour with sweet, mild bitter with sweet and tasteless) were eaten by the frugivorous birds in MNP. The birds preferred to eat mild sweet fruits most $(22.9 \%$ of the used plant species), followed by sweet (20.8\% of the exercised plant species), mild sour $(16.7 \%$ of the exploited plant species) and mixed taste (mild sour with sweet) $16.3 \%$ of the utilized plant species). The frugivorous birds in MNP ate only one tasteless fruit (Bridelia scandens) and one mild bitter with sweet fruit (Callicarpa arborea).

Duration of fruiting time of the used plant species: The fruiting time of plant species, whose fruits were eaten by frugivorous birds in MNP lasted from 2 to 12 months. The fruiting time of 19 exploited species lasted for 2 months, 18 species 3 months, 6 species 4 months and 2 species lasted for 6 months. Furthermore, there were two different species (Grewia asiatica and Carica papaya), whose fruiting time stretched for 7 and 12 months respectively.

Monthly variation of flowering and fruiting plants: In MNP the flowering time of the used food plant species was maximum (12 species i.e., 25\%) during March 
and April 2008 and the highest fruiting trees (24 species i.e., 50\%) in April 2008, whereas the minimum flowering (1 species i.e., $2.1 \%$ ) was observed in December 2008 and the lowest fruiting (3 species i.e., 6.3\%) in July 2007. Frankie et al. (1974) recorded the peak fruiting of fleshy-fruited plants during the dry season in the dry deciduous forest of Costa Rica. The fruiting of maximum species (33) of ornamental and shrub species was observed in the month of March and minimum (11) in October at the Chittagong University Campus of Bangladesh (Hoque 1999).

Highest preference for fruit plant by the bird species: A single species of bird consumed fruits from a variety of food plants as diets; on the other hand, different species of birds also ate from a single species of plant. For instance (Fig. 4), Red-vented Bulbul ate fruits from 38 species of plants in MNP. Eight species of birds (Red-breasted Parakeet, Golden-fronted Leafbird, Black-naped Oriole, Common Iora, Oriental White-eye, Jungle Babbler, Purple Sunbird and Pale-billed Flowerpecker) ate fruit from a single plant species (Fig. 4). Lever (1987) mentioned that various bulbul species are dominant or important frugivores in secondary vegetation throughout tropical and subtropical Asia, as well as much of Africa and the Middle East. Kamruzzaman (2004) also noted that the Red-vented Bulbul visited the maximum number (23) of plants species at the Chittagong University Campus.

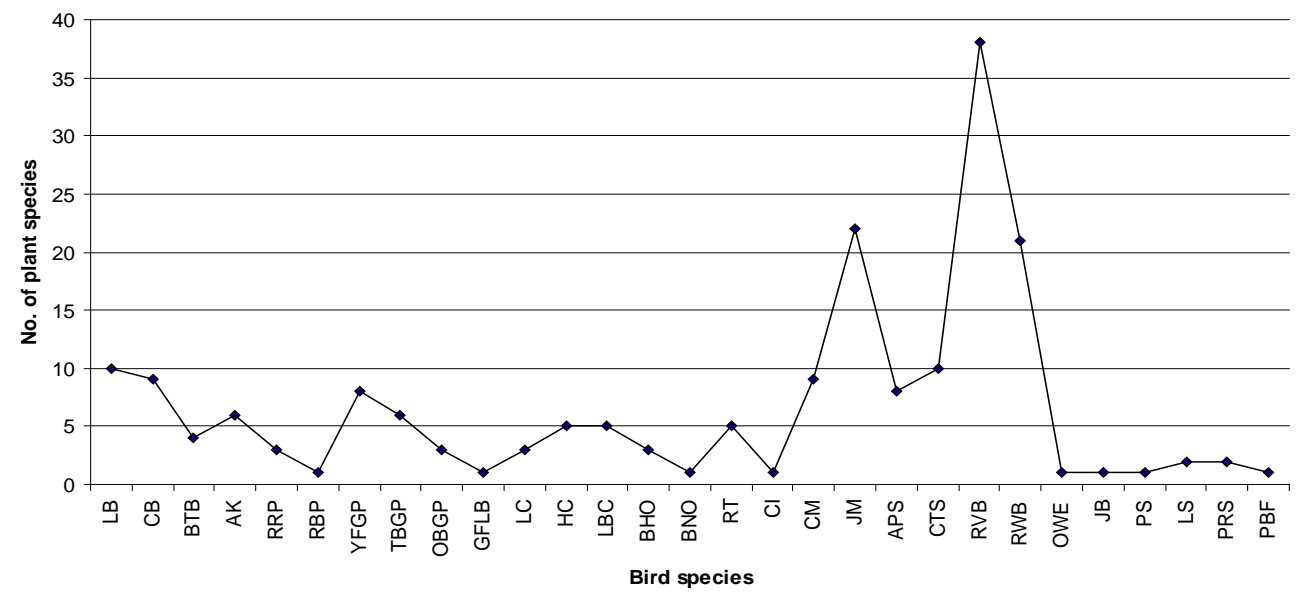

Fig. 4. Number of plant species used by each bird species.

Ornithophily plant species: Pollination by bird is commonly known as ornithophily bird and the plan on which it occurs is termed as ornithophily plant (Fægri and Pijl 1971). Ten (20.8\%) species of ornithophily plants were recorded in the MNP. In New Zealand, there are over 30 plant species, whose flowers are visited by birds (Godley 1979, Craig et al. 1981). About 100 families of flowering plants are known to have at least some members adapted for birdpollination (Meeuse and Morris 1984). 
Distribution of food plant: Maximum food plant species (81\%) were located along the Tangail-Mymensingh Highway, which passes near adjacent the southern boundary line of the national park. Few scattered food plants were observed during the fieldwork. Only a few Ficus benghalensis and some Antidesma ghasembilla plants were recorded from dense forest of the MNP.

Unused plant species: Fifteen species of fruiting plants (belonging to 11 families) were recorded from the MNP, whose fruits were not used as food by the frugivorous birds (Table 2). Family Euphorbiaceae comprised the maximum number of unused species (i.e., 4).

Table 2. Unused plant species by the frugivorous bird species at MNP.

\begin{tabular}{lll}
\hline S1. No. & Family & Scientific name \\
\hline 1. & Anacardaceae & Laena cormondelica \\
2. & Combretaceae & Terminalia belerica (Roxb.) \\
3. & Euphorbiaceae & Aporusa diocia (Roxb.) Muell. (A. roxburghii Baill.) \\
4. & Euphorbiaceae & Antidesma acidum (Retz.) (A. diandrum (Roxb.) Roth) \\
5. & Euphorbiaceae & Phyllanthus reticulatus Poir. \\
6. & Euphorbiaceae & Glochidion multilicularae Muell. Arg. \\
7. & Lecythidaceae & Barringtonia acutangula (L.) Gaertn. \\
8. & Leeaceae & Leea alata \\
9. & Menispermaceae & Cocculus hirsutus (L.) Diels. \\
10. & Myrsinaceae & Maesa indica Wall \\
11. & Rubiaceae & Xeromphis spinosa (Thumb.) Keay (Randia dumetorum \\
12. & Ulmaceae & Lamk.) \\
13. & Verbenaceae & Trema politoria \\
14. & Verbenaceae & Duranta repens L. (D. plumeri Jacq.) \\
15. & Vitaceae & Vitis repensi Wt. \& Arm. \\
\hline
\end{tabular}

Acknowledgements: This work would not be possible without the financial supports of the project 'Ecology, behaviour and conservation of some wildlife of Bangladesh'. Thanks are due to Professor Dr. Eivin Røskaft, (Institutt for Biologi, Fakultet for Naturvitenskap of Teknologi, Norges Teknisk-Naturvitenskapelige Universitet), Professor Dr. Arne Moksnes and Dr. Bård G. Stokke, Researcher, Department of Biology, Norwegian University of Science and Technology, Trondheim, Norway for their suggestions and encouragement during the fieldwork. We also like to extend our indebtedness to Professor Dr. M. Kamal Pasha, Department of Botany, University of Chittagong, Chittagong, Bangladesh, for identifying the herbaria of the plants. Sincere thanks to Mr. Tauhid Uddin Ahmed, Ex-Principal Scientific Officer, IEDCER, Mohakhali, Bangladesh for his valuable comments to enrich the manuscript. 


\section{LITERATURE CITED}

ALI, S. and RIPLEY, S.D. 1996. The book of Indian birds, 12 th edition. Bombay Natural History Society, Mumbai. 354 pp.

ANONYMOUS. 2008. Population density and feeding pattern of frugivorous birds in five protected areas of Bangladesh. Unpublished M.Sc. Thesis. Department of Zoology, Jahangirnagar University, Savar, Dhaka, Bangladesh. 98 pp.

BALASUBRAMANIAN, P. 1996. Interactions between fruit-eating birds and bird-dispersed plants in the tropical dry-evergreen forest of Point Calimere, South India. $J$. Bombay Nat. Hist. Soc. 93: 428-441.

BLAKE, J.G. and LOISELLE, B.A. 1992. Fruits in the diets of Neotropical migrant birds in Costa Rica. Biotrop. 24: 200.

BUCKLAND, S.T., ANDERSON, D.R., BURRHAM, K.P., LAAKE, J.L., BORCHERS, D.L. and THOMAS, L. 2001. Introduction to distance sampling: estimating abundance of biological populations. Oxford University Press, Oxford. $432 \mathrm{pp}$.

CRAIG, J.L., STEWART, A.M. and DOUGLAS, M.E. 1981. The foraging of New Zealand honeyeaters. New Zealand J. Zool. 8: 87-91.

DOWSELT-LEMAIRE, F. 1988. Fruit choice and seed dissemination in the evergreen forests of upland Malawi. Rev. Ecol. (Terre et vie). 43: 251-285.

ESTRADA, A., COATES-ESTRADA, R., JR. MERITT, D.A., MONTIE S. and CURIEL, D. 1993. Patterns of frugivore species richness and abundance in forest islands and in agricultural habitats at Los Tuxtlas, Mexico. Vegetatio. 107/108: 245-257.

F/EGRI, K. and PIJL, L.V.D. 1971. The principles of pollination ecology. Pergamon Press, Oxford. $291 \mathrm{pp}$.

FATEM, S., SAWEN, D. and KILMASKOSSU, M.S.E. 2008. Dry matter and organic value of cuscus diet in West Papua. Tigerpaper. 35(2): 7-21.

FOGDEN, M.P.L. 1970. Some aspects of the ecology of bird populations in Sarawak. Unpublished Ph.D. Thesis, University of Oxford, Oxford.

FOSTER, M.S. 1987. Feeding methods and efficiencies of selected frogivorous birds. The Condor. 89: 566-580.

FRANKIE, G.W., BAKER, H.G. and OPLER, P.A. 1974. Comparative phonological studies of trees in tropical wet and dry forests in the lowlands of Costa Rica. Ecol. 62: 881919.

GODLEY, E. J. 1979. Flower biology in New Zealand. New Zealand Journal of Botany. 17: 442-446.

GOSPER, C.R., STANSBURY, C.D. and VIVIAN-SMITH, G. 2005. Seed dispersal of fleshyfruited invasive plants by birds: contribution factors and management options. Diversity Distrib. 11: 549-558.

GRIMMETT, R., INSKIPP, C. and INSKIPP, T. 1998. Birds of the Indian Subcontinent. Oxford University Press, Delhi. 888 pp.

HERRERA, C.M. 1984. A study of avian frugivores, bird-dispersed plants and their interaction in Mediterranean scrublands. Ecol. Monogr. 54: 1-23. 
HERRERA, C.M., JORDANO, P., LÓPEZ-SORIA, L. and AMAT, J. 1994. Recruitment of a mast-fruiting, bird-dispersed tree: bridging frugivory activity and seedling establishment. Ecol. Monogr. 64: 315-344.

HOQUE, M.M. 1999. Studies on the phenology of some ornamental plants and shrubs at Chittagong University Campus. Unpublished M.Sc. Thesis, Department of Zoology, University of Chittagong, Chittagong. $168 \mathrm{pp}$.

HOWE, H.F. 1977. Bird activity and seed dispersal of a tropical wet forest tree. Ecol. 58: 539-550.

HOWE, H.F. 1984. Implications of seed dispersal by animals for tropical reserve management. Biol. Conserv. 30: 261-281.

HOWE, H.F. and ESTABROOK, G.F. 1977. On intraspecific competition for avian dispersers in tropical trees. Am. Nat. 111: 817-832.

HOWE, H.F. and VAN DE KERCKHOVE, G.A. 1980. Nutmeg dispersal by tropical birds. Sci. 210: 925-927.

JORDANO, P. 1995. Spatial and temporal variation in the avian-frugivore assemblage of Prunus mahaleb: patterns and consequences. Oikos. 71: 479-491.

KAMRUZZAMAN, M. 2004. Fruiting phenology and avian frugivore relationship in the Chittagong University Campus. Unpublished M.Sc. Thesis. Department of Zoology, University of Chittagong, Chittagong. 59 pp.

KAMRUZZAMAN, M. and ASMAT, S.M. 2008. Seasonal variations of fruit among frugivorous birds in Chittagong, Bangladesh. Bangladesh J. Zool. 36(2): 187-206.

KANTAK, G.E. 1979. Observation on some fruit-eating birds in Mexico. Auk. 96: 183-186.

KHAN, M.A.R. 1982. Wildlife of Bangladesh-a checklist. University of Dhaka, Dhaka. 173 pp.

LAMBERT, F.R. 1987. Fig-eating and seed dispersal by birds in a Malaysian lowland rain forest. Unpublished Ph.D. Thesis, Department of Zoology, University of Aberdeen, Aberdeen. 310 pp.

LAND, H. C. 1963. A tropical feeding tree. Wilson Bull. 75: 199-200.

LECK, C.F. 1969. Observation of birds exploiting a Central American fruit tree. Wilson Bull. 81: 264-269.

LECK, C.F. 1971 Overlap in the diet of some Neotropical birds. Living Bird. 10: 84-106.

LEIGHTON, M. 1982. Fruit resources and patterns of feeding, spacing and grouping among sympatric Bornean hornbills (Bucerotidae). Unpublished Ph.D. Thesis, University of California, Davis.

LEIGHTON, M. and LEIGHTON, D.R. 1983. Vertebrate responses to fruiting seasonality within a Bornean rain forest. Pp. 181-196. In: SUTTON, S.L., WHITMORE, T.C. AND CHADWICK, (Eds.): Tropical rain forest: ecology and management. Blackwell, Oxford.

LEVER, C. 1987. Naturalized birds of the world. Longman, England.

LEVEY, D.J., SILVA, W.R. and GALETTI, M. 2002. Seed dispersal and frugivory: ecology, evolution and conservation. CAB International, Wallingford. 
MCDIARMID, R.W., RICKLEFS, R.E. And FOSTER, M.S. 1977. Dispersal of Stemmadenia donnell-smithii (Apocynaceae) by birds. Biotrop. 9: 9-25.

MCKEY, D. 1975. The ecology of coevolved seed dispersal systems. pp. 159-191. In: GILBERT, L.E. and RAVEN, P.H. (Eds.). Coevolution of animals and plants. University of Texas, Austin, Texas.

MEEUSE, B. and MORRIS, S. 1984. The sex life of flowers. Facts on File, New York.

MOERMOND, T.C. and DENSLOW, J.S. 1985. Neotropical avian frugivores: patterns of behavior, morphology and nutrition with consequences for fruit selection. pp. 1041. In: BUCKLEY, P.A, FOSTER, M.S., MORTON, E.S., RIDGELY, R.S. and BUCKLEY, F.S. (Eds.): Neotropical Ornithology, Ornithological Monograph, No. 36. American Ornithologists Union, Washington D.C.

MURRAY, K.G., WINNETT-MURRAY, K., CROMIE, E.A., MINOR, M. and MEYERS, E. 1993. The influence of seed packaging and fruit colour on feeding preferences of American robins. Vegetatio. 107/108: 217-226.

RAJU, A.J.S. 2005. Passerine bird pollination and seed dispersal in Woodfordia floribunda Salisb. (Lythraceae), a common low altitude woody shrub in the Eastern Ghats forests of India. Ornithol. Sci. 4: 103-108.

SNOW, D.W. 1971. Evolutionary aspects of fruit-eating by birds. Ibis. 113: 194-202.

SNOW, D.W. 1981. Tropical frugivorous birds and their food plants: A World Survey. Biotrop. 13(1): 1-14.

TAKANOSE, Y. and KAMITANI, T. 2003. Fruiting of fleshy-fruited plants and abundance of frugivorous birds: phenological correspondence in a temperate forest in central Japan. Orni. Sci. 2: 25-32.

TERBORGH, J.W. 1986. Community aspects of frugivory in tropical forests. pp. 371-384. In: ESTRADA, A. and FLEMING, T.H. (Eds.): Frugivores and seed dispersal. W. Junk. Publisher, Netharlands.

WHEELWRIGHT, N.T. and JANSON, C.H. 1985. Colors of fruit displays of bird-dispersed fruits in two tropical forests. Am. Nat. 126: 777-799.

WILLSON, M.F. and THOMPSON, J.N. 1982. Phenology and ecology of color in birddispersed fruits or why some fruits are red when they are 'green'? Canadian J. Bot. 60: $701-713$.

WILLSON, M.F., IRVINE, A.K. and WALSH, N.G. 1989. Vertebrate dispersal syndromes in some Australian and New Zealand plant communities, with geographic comparisons. Biotrop. 21(2): 133-147.

(Manuscript received on 4 May, 2015; revised on 30 December, 2015) 